\title{
Hundreds of Unrecognized Halogenated Contaminants Discovered in Polar Bear Blood
}

Yanna Liu, ${ }^{[a]}$ Evan S. Richardson, ${ }^{[b]}$ Andrew E. Derocher, ${ }^{[c]}$ Nicholas J. Lunn, ${ }^{[d]}$ Hans-Joachim Lehmler, ${ }^{[e]}$ Xueshu Li, ${ }^{[e]}$ Yifeng Zhang, ${ }^{[a]}$ Julia Yue Cui, ${ }^{[f]}$ Lihua Cheng ${ }^{[f]}$ and Jonathan W. Martin ${ }^{*}\left[{ }^{[a]}[\mathrm{g}]\right.$

[a] Division of Analytical and Environmental Toxicology, Department of Laboratory Medicine and Pathology, University of Alberta, Edmonton, Alberta T6G 2G3, Canada

[b] Wildlife Research Division, Science and Technology Branch, Environment and Climate Change Canada, Government of Canada, Winnipeg, Manitoba R3C 4W2, Canada

${ }^{[c]}$ Department of Biological Sciences, University of Alberta, Edmonton, Alberta T6G 2E9, Canada

[d] Wildlife Research Division, Science and Technology Branch, Environment and Climate Change Canada, Edmonton, Alberta T6G 2E9, Canada

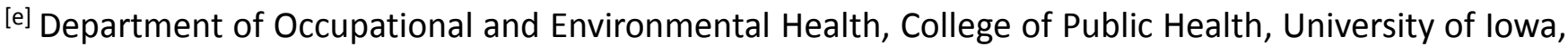
lowa City, lowa 52242-5000, USA

[f] Department of Environmental \& Occupational Health Sciences, University of Washington, Seattle, Washington 98105-6099, USA

${ }^{[\mathrm{g}]}$ Science for Life Laboratory, Department of Environmental Science and Analytical Chemistry, Stockholm University, Stockholm 10691, Sweden

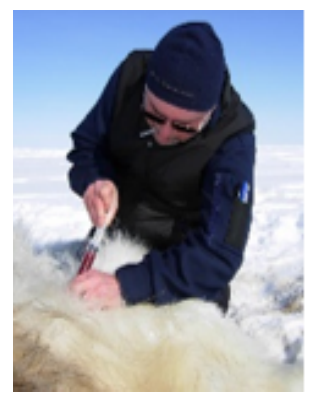

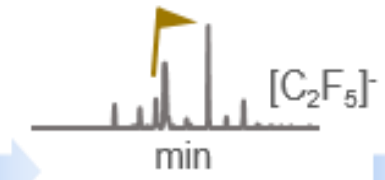

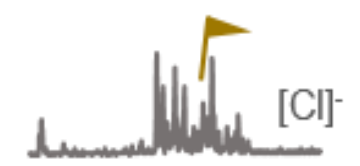

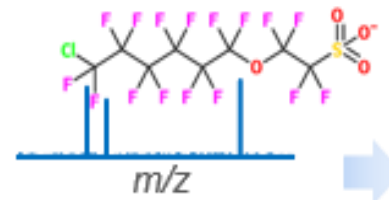

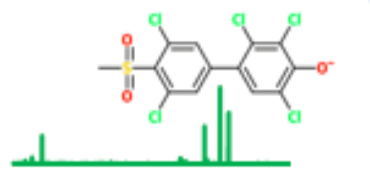

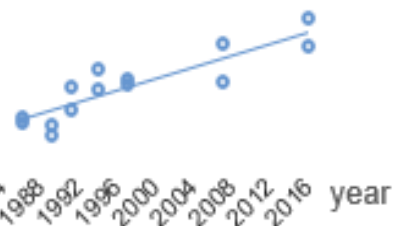

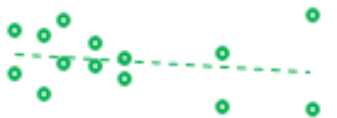

* To whom correspondence should be addressed. Email: jon.martin@aces.su.se 
Exposure of polar bears (Ursus maritimus) to persistent organic pollutants was discovered in the 1970s, but recent evidence suggests the presence of unknown toxic chemicals in their blood. Protein and phospholipid depleted serum was stirred with polyethersulfone capillaries to extract a broad range of analytes, and nontarget mass spectrometry with "fragmentation flagging" was used for detection. Hundreds of analytes were discovered belonging to 13 classes, including novel polychlorinated biphenyl (PCB) metabolites and many fluorinated or chlorinated substances not previously detected. All analytes were detected in the oldest (mid-1980s) archived polar bear serum from Hudson Bay and Beaufort Sea, and all fluorinated classes showed increasing trends. A mouse experiment confirmed the novel PCB metabolites, suggesting that these could be widespread in mammals. Historical exposure and toxic risk has been underestimated, and emerging contaminants pose uncertain risks to this threatened species.

Keywords: environmental chemistry $\bullet$ halogenated contaminants $\bullet$ mass spectrometry $\bullet$ nontarget discovery $\bullet$ polar bear

Polar bears (Ursus maritimus) are apex predators of the Arctic marine foodweb, making them vulnerable to bioaccumulative and persistent chemicals transported long-range from mid-latitudes. Since from the 1970s, many halogenated contaminants have been identified in polar bears ${ }^{[1]}$, including polychlorinated biphenyls (PCBs), dichlorodiphenyltrichloroethane (DDE) and perfluoroalkyl acids. These problematic discoveries in the Arctic led to classification of such substances as Persistent Organic Pollutants (POPs), and have enabled international regulatory bans or restrictions on these chemicals under the Stockholm Convention ${ }^{[2]}$. However, in polar bear blood there are still unidentified toxic contaminants. In an attempt to identify all chemicals in polar bear blood that disrupt thyroid hormone binding, the authors concluded that $25 \%$ of the biological activity was from unidentified chemicals ${ }^{[3]}$. Known contaminants and certain metabolites are linked to adverse health effects in polar bears, such as immune-suppression and endocrine disruption ${ }^{[4]}$. Contaminants in polar bears are also a health concern to indigenous people who depend on marine mammals for subsistence. Discovering the unknown environmental pollutants in polar bears is therefore of great importance for the conservation and management of polar bears, and the health of the Arctic ecosystem.

Here we analyzed pooled polar bear serum from each of the Hudson Bay and Beaufort Sea subpopulations in the Canadian Arctic with the aim of detecting unknown fluorinated or chlorinated global contaminants of biological relevance. A stir bar-assisted sorptive method was developed for sample extraction and a non-target high resolution mass spectrometry (Nt-HRMS) method was used for unknown discovery ${ }^{[5]}$. A controlled mouse study was then performed to confirm the novel PCB 
metabolites discovered in polar bears. Finally, temporal trends of all discovered halogenated contaminants were analyzed in archived samples from the two locations dating to the mid-1980s. Our study suggests that historical exposure and toxic risk in polar bears has been underestimated, and health risks posed by these emerging halogenated pollutants should be evaluated.

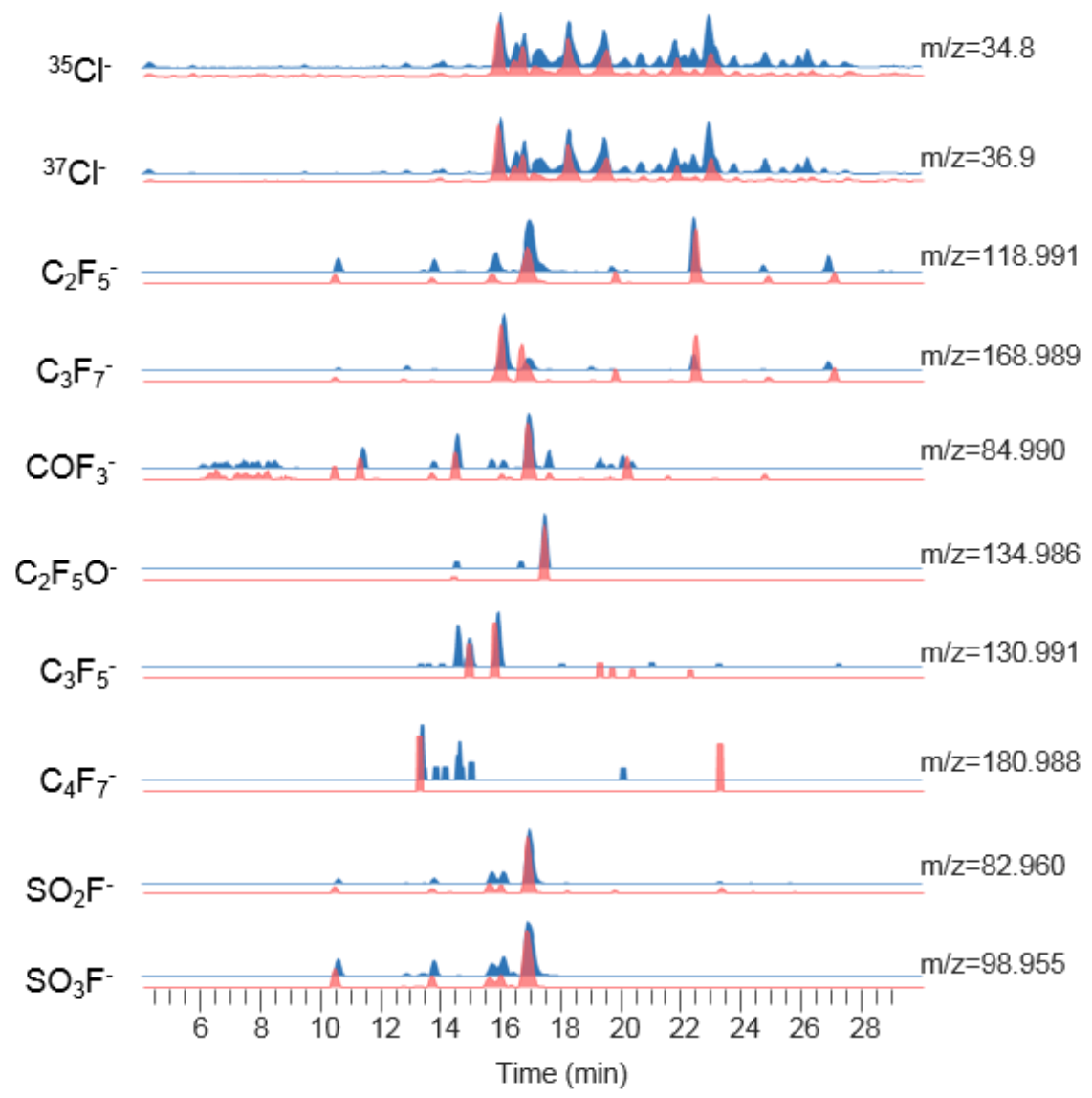

Figure 1. Extracted chromatograms of in-source fluorine- and chlorine-related fragments in pooled polar bear serum from Hudson Bay (blue traces) and Beaufort Sea (red traces).

Using model fluorinated and chlorinated standards (Table S1), we developed a new polyethersulfone stir bar-assisted sorptive extraction method capable of extracting from up to $10 \mathrm{~mL}$ of serum. The method showed high sensitivity (Table S2) and reliable recovery (Figure S1). Representative pooled serum from Hudson Bay and Beaufort Sea (Table S3) were then extracted, and subjected to a previously developed Nt-HRMS method for unknown organohalogen discovery. In-source fragmentation flagging in the two extracts showed hundreds of chromatographic peaks (e.g. $\left[{ }^{35} \mathrm{Cl}^{-},\left[\mathrm{C}_{2} \mathrm{~F}_{5}\right]^{-}\right.$, and $\left[\mathrm{SO}_{3} \mathrm{~F}\right]^{-}$) corresponding to organochlorine and organofluorine analytes (Figure 1). While some of these peaks corresponded to known analytes such as perfluoroalkyl acids and hydroxylated PCBs (OH-PCBs), the vast majority corresponded to analytes not previously detected in polar bears. Complete Nt-HRMS analyses over these 
peaks revealed 13 classes of new halogenated contaminants, including 5 classes of PCB Metabolites (Class 1.1-1.5, 181 analytes), 4 classes of Perfluoroalkyl Sulfonates (PFSAs, Class 2.1-2.4, 35 analytes), and 4 classes of Other Polychlorinated Compounds (Class 3.1-3.4, 8 analytes). Detailed discovery and characterization of these halogenated contaminants are presented below. For the PCB metabolites, the confirmation in mice is also discussed, where mice were exposed to a PCB-mixture or vehicle control at 0,6 and $30 \mathrm{mg} / \mathrm{kg}$.

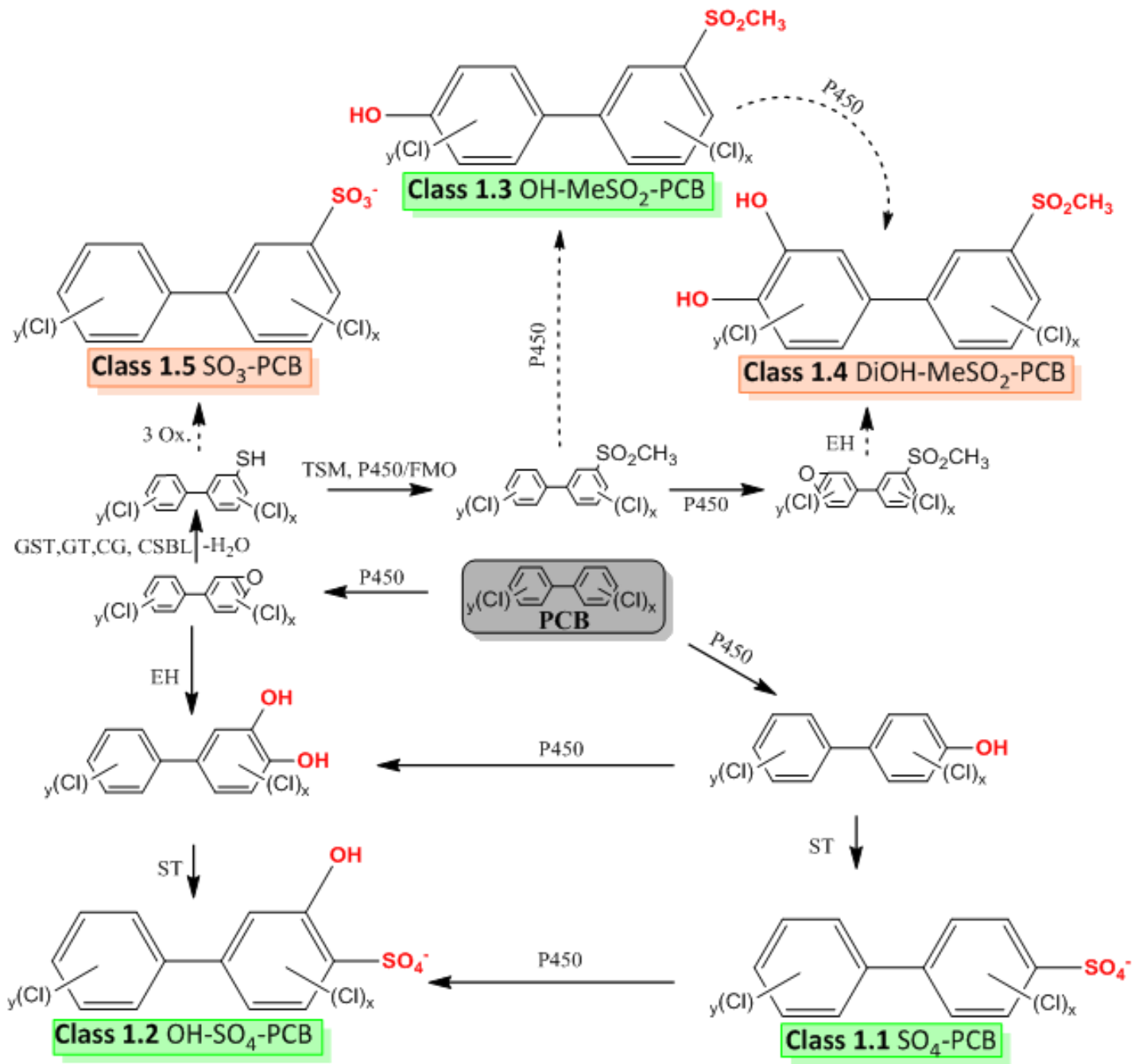

$\mathrm{P} 450=$ cytochrome $\mathrm{P} 450 ; \mathrm{EH}=$ epoxide hydrolase; $\mathrm{ST}=$ sulfotransferase; GST = glutathione-S-transferase; $\mathrm{GT}=$ gamma-glutamyl transpeptidase; $\mathrm{CG}=$ cysteinylglycinase; $\mathrm{CSBL}=$ cysteine S-conjugate beta-lyase; $\mathrm{TSM}=$ thiol S-methyltransferase; $\mathrm{DD}=$ dihydrodiol dehydrogenase; $\mathrm{FMO}=$ flavin containing monooxygenase

\section{Known Class in PBs \\ +more congeners detected \\ New Class in PBs \\ First report in polar bears}

\section{Novel Class \\ First report in literature}

Established Pathway

$\overrightarrow{\text { Proposed Pathway }}$

Figure 2. Summary scheme of established ${ }^{[6]}$ and newly proposed PCB biotransformation pathways in polar bears. Example representative structures shown, positions of functional groups and Cl-substitution are uncertain. 

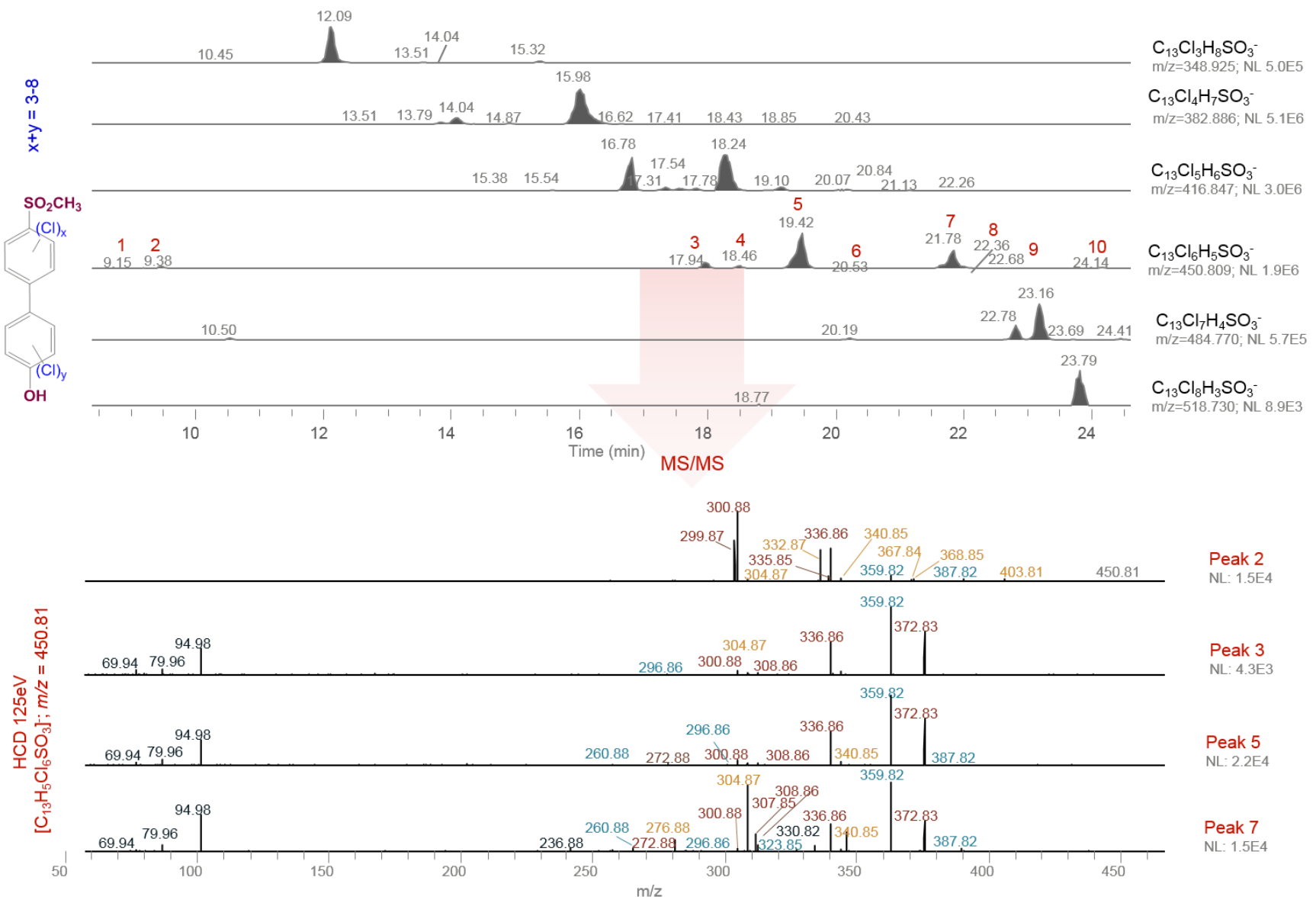

$\mathrm{m} / \mathrm{z}=372.82:\left[\mathrm{C}_{12} \mathrm{Cl}_{6} \mathrm{H}_{3} \mathrm{O}\right]-=[\mathrm{M}]-\mathrm{SO}_{2} \mathrm{CH}_{2}$ $\mathrm{m} / \mathrm{z}=336.86:\left[\mathrm{C}_{12} \mathrm{Cl}_{5} \mathrm{H}_{2} \mathrm{O}\right]^{-}=[\mathrm{M}]^{-}-\mathrm{SO}_{2} \mathrm{CH}_{2}-\mathrm{HCl}$ $\mathrm{m} / \mathrm{z}=308.86:\left[\mathrm{C}_{11} \mathrm{Cl}_{5} \mathrm{H}_{2}\right]^{-}=[\mathrm{M}]^{-}-\mathrm{SO}_{2} \mathrm{CH}_{2}-\mathrm{HCl}-\mathrm{CO}$ $\mathrm{m} / \mathrm{z}=300.88:\left[\mathrm{C}_{12} \mathrm{Cl}_{4} \mathrm{HO}\right]^{-}=[\mathrm{M}]-\mathrm{SO}_{2} \mathrm{CH}_{2}-2 \mathrm{HCl}$ $\mathrm{m} / \mathrm{z}=272.88:\left[\mathrm{C}_{11} \mathrm{Cl}_{4} \mathrm{H}\right]^{-}=[\mathrm{M}]-\mathrm{SO}_{2} \mathrm{CH}_{2}-2 \mathrm{HCl}-\mathrm{CO}$ $\mathrm{m} / \mathrm{z}=335.85:\left[\mathrm{C}_{12} \mathrm{Cl}_{5} \mathrm{HO}\right]^{-*}=[\mathrm{M}]^{-\cdot} \cdot \mathrm{SO}_{2} \mathrm{CH}_{3}-\mathrm{HCl}$ $\mathrm{m} / \mathrm{z}=307.85:\left[\mathrm{C}_{11} \mathrm{Cl}_{5} \mathrm{H}\right]^{-*}=[\mathrm{M}]^{-} \cdot-\mathrm{SO}_{2} \mathrm{CH}_{3}-\mathrm{HCl}-\mathrm{CO}$ $\mathrm{m} / \mathrm{z}=299.87:\left[\mathrm{C}_{12} \mathrm{Cl}_{4} \mathrm{O}\right]^{-}=[\mathrm{M}]^{--}-\mathrm{SO}_{2} \mathrm{CH}_{3}-2 \mathrm{HCl}$

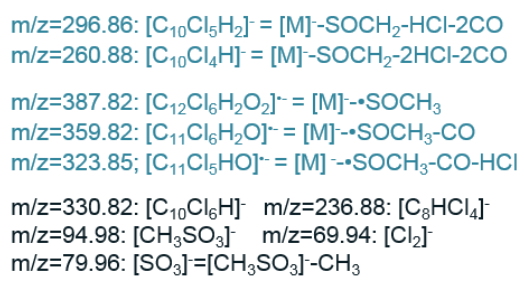
$\mathrm{m} / \mathrm{z}=260.88:\left[\mathrm{C}_{10} \mathrm{Cl}_{4} \mathrm{H}\right]=[\mathrm{M}]-\mathrm{SOCH}_{2}-2 \mathrm{HCl}-2 \mathrm{CO}$ $\mathrm{m} / \mathrm{z}=387.82:\left[\mathrm{C}_{12} \mathrm{Cl}_{6} \mathrm{H}_{2} \mathrm{O}_{2}\right]^{--}=[\mathrm{M}]^{-} \cdot-\mathrm{SOCH}_{3}$ $\mathrm{m} / \mathrm{z}=359.82:\left[\mathrm{C}_{11} \mathrm{Cl}_{6} \mathrm{H}_{2} \mathrm{O}\right]^{-*}=[\mathrm{M}]^{-} \cdot-\mathrm{SOCH}_{3}-\mathrm{CO}$ $\mathrm{m} / \mathrm{z}=323.85 ;\left[\mathrm{C}_{11} \mathrm{Cl}_{5} \mathrm{HO}^{-\cdots}=[\mathrm{M}]--\cdot \mathrm{SOCH}_{3}-\mathrm{CO}-\mathrm{HCl}\right.$ $\mathrm{m} / \mathrm{z}=330.82:\left[\mathrm{C}_{10} \mathrm{Cl}_{6} \mathrm{H}\right]^{-} \quad \mathrm{m} / \mathrm{z}=236.88:\left[\mathrm{C}_{8} \mathrm{HCl}_{4}\right]$ $\mathrm{m} / \mathrm{z}=94.98:\left[\mathrm{CH}_{3} \mathrm{SO}_{3}\right]^{-} \mathrm{m} / \mathrm{z}=69.94:\left[\mathrm{Cl}_{2}\right]$ $\mathrm{m} / \mathrm{z}=79.96:\left[\mathrm{SO}_{3}\right]=\left[\mathrm{CH}_{3} \mathrm{SO}_{3}\right]-\mathrm{CH}_{3}$

$\mathrm{m} / \mathrm{z}=368.85:\left[\mathrm{C}_{12} \mathrm{Cl}_{5} \mathrm{H}_{2} \mathrm{O}_{3}\right]=[\mathrm{M}]-\mathrm{SCH}_{2}-\mathrm{HCl}$ $\mathrm{m} / \mathrm{z}=340.85:\left[\mathrm{C}_{11} \mathrm{Cl}_{5} \mathrm{H}_{2} \mathrm{O}_{2}\right]=[\mathrm{M}]-\mathrm{SCH}_{2}-\mathrm{HCl}-\mathrm{CO}$ $\mathrm{m} / \mathrm{z}=332.87:\left[\mathrm{C}_{12} \mathrm{Cl}_{4} \mathrm{HO}_{3}\right]^{-}=[\mathrm{M}]-\mathrm{SCH}_{2}-2 \mathrm{HCl}$ $\mathrm{m} / \mathrm{z}=304.87:\left[\mathrm{C}_{11} \mathrm{Cl}_{4} \mathrm{HO}_{2}\right]=[\mathrm{M}]-\mathrm{SCH}_{2}-2 \mathrm{HCl}-\mathrm{CO}$ $\mathrm{m} / \mathrm{z}=276.88:\left[\mathrm{C}_{10} \mathrm{Cl}_{4} \mathrm{HO}\right]^{-}=[\mathrm{MM}]-\mathrm{SCH}_{2}-2 \mathrm{HCl}-2 \mathrm{CO}$ $\mathrm{m} / \mathrm{z}=403.81:\left[\mathrm{C}_{12} \mathrm{Cl}_{6} \mathrm{H}_{2} \mathrm{O}_{3}\right]^{-}=[\mathrm{M}]^{-}-\bullet \mathrm{SCH}_{3}$ $\mathrm{m} / \mathrm{z}=367.84:\left[\mathrm{C}_{12} \mathrm{Cl}_{5} \mathrm{HO}_{3}\right]^{-}=[\mathrm{M}]^{-} \cdot-\mathrm{SCH}_{3}-\mathrm{HCl}$

Figure 3. Extracted chromatograms of Class $1.3 \mathrm{OH}-\mathrm{SO}_{2} \mathrm{CH}_{3}-\mathrm{PCB}$ congeners in the Hudson Bay pooled polar bear serum, MS/MS spectra of selected $\mathrm{Cl}_{6}$ - congeners and proposed fragmentation mechanisms for each product ion

Metabolism of PCBs has been extensively studied and reviewed ${ }^{[6 a]}$ (Figure 2). In addition to OH-PCBs (Figure S3) and dihydroxylated PCBs (DiOH-PCBs, Figure S4), which are known contaminants in polar bears $^{[7]}$, we detected 5 more classes of metabolites (Table 1). The first two classes are PCB-Sulfates (Class 1.1, SO4-PCBs) and OH-PCB-Sulfates (Class 1.2, OH-SO4-PCBs). Both classes had diagnostic MS/MS spectra showing neutral loss of SO3 from the molecular ion (Figures S5.1 and S6), and two SO4-PCBs were confirmed by authentic standards. In total, $>50$ SO4-PCBs and $>40 \mathrm{OH}-\mathrm{SO} 4-\mathrm{PCBs}$ were detected, and this is their first report in polar bears. We confirmed the dose-response production of $\mathrm{Cl} 2$ - to $\mathrm{Cl}$ SO4-PCBs and of $\mathrm{Cl} 1$ - to $\mathrm{Cl} 8-\mathrm{OH}-\mathrm{SO} 4-\mathrm{PCBs}$ in mice exposed to a $\mathrm{PCB}$ mixture (Figure S2). Retention times of the unknown congeners in polar bears and experimental mice were similar, thereby increasing confidence in the core PCB structures, and only the chlorine substitution patterns remain uncertain. 

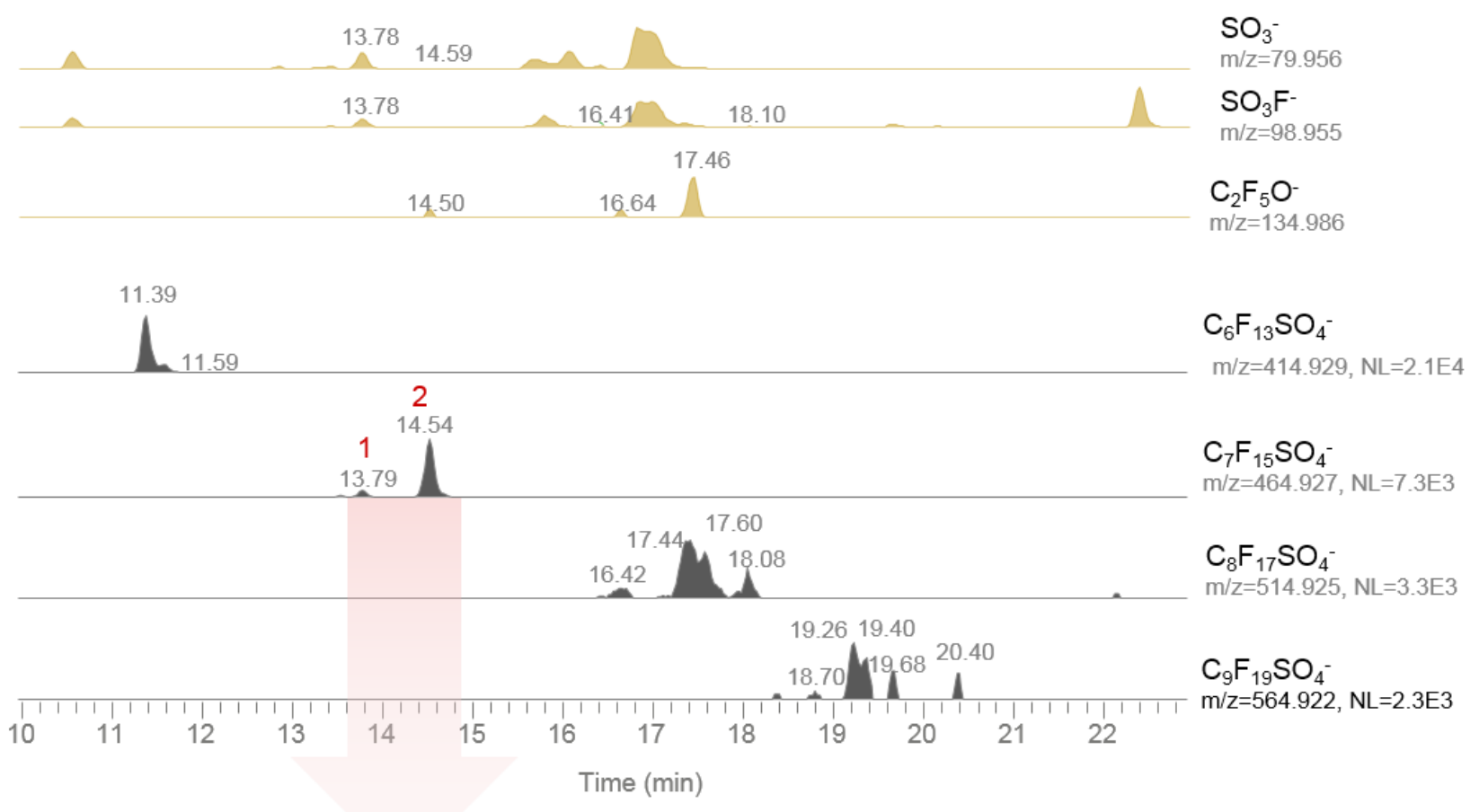

$\mathrm{C}_{9} \mathrm{~F}_{19} \mathrm{SO}_{4}^{-}$

$\mathrm{m} / \mathrm{z}=564.922, \mathrm{NL}=2.3 \mathrm{E} 3$

MS/MS

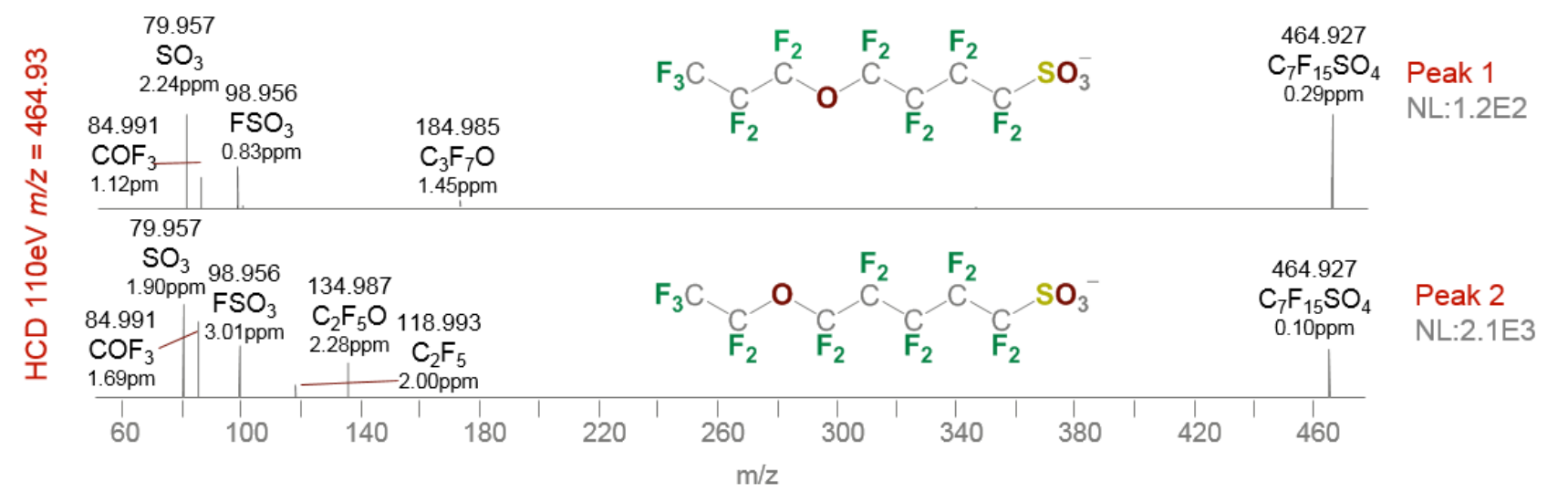

Figure 4. Extracted chromatograms of in-source $\left.\left[\mathrm{SO}_{3}\right]^{-}, \mathrm{SO}_{3} \mathrm{~F}\right]^{-}$and $\left[\mathrm{C}_{2} \mathrm{~F}_{5} \mathrm{O}\right]^{-}$fragments (brown peaks) and Class $\mathbf{2 . 2}$ Ether-PFSA homologs (grey peaks) in the Hudson Bay pooled polar bear serum, and MS/MS of the C7-homolog Proposed structures for two C7-homolog isomers are shown

The next two classes of PCB metabolites are derivatives of methylsulfone-PCBs $\left(\mathrm{SO}_{2} \mathrm{CH}_{3}-\mathrm{PCBs}\right)^{[6 a]}$ (Figure 2), specifically Hydroxylated $\mathrm{SO}_{2} \mathrm{CH}_{3}-\mathrm{PCBs}$ (Class 1.3, $\mathrm{OH}-\mathrm{SO}_{2} \mathrm{CH}_{3}-\mathrm{PCBs},>40$ congeners) and Dihydroxylated $\mathrm{SO}_{2} \mathrm{CH}_{3}-\mathrm{PCBs}$ (Class 1.4, DiOH- $\mathrm{SO}_{2} \mathrm{CH}_{3}-\mathrm{PCBs},>20$ congeners). To our knowledge, the $\mathrm{DiOH}-\mathrm{SO}_{2} \mathrm{CH}_{3}-\mathrm{PCBs}$ have never been reported, and the only previous report of $\mathrm{OH}-\mathrm{SO}_{2} \mathrm{CH}_{3}-\mathrm{PCBs}$ was in people accidentally poisoned by cooking oil contaminated with $\mathrm{PCBs}^{[8]}$. The $\mathrm{MS} / \mathrm{MS}$ spectra of $\mathrm{OH}-$ $\mathrm{SO}_{2} \mathrm{CH}_{3}-\mathrm{PCBs}$ were relatively complex, but most congeners showed an initial diagnostic loss of $\mathrm{SO}_{2} \mathrm{CH}_{2}$ (Figure 3), demonstrating the methylsulfone functionality. The third oxygen atom was typically lost as 
$\mathrm{CO}$, consistent with a core $\mathrm{OH}-\mathrm{PCB}$ structure. Similarly, the $\mathrm{DiOH}-\mathrm{SO}_{2} \mathrm{CH}_{3}-\mathrm{PCBs}$ also had highly diagnostic loss of the methylsulfone moiety and subsequent neutral losses of $\mathrm{HCl}$ and $\mathrm{CO}$ (Figure S7). This class could be formed in mammals by sequential hydroxylation, or epoxidation and hydrolysis of $\mathrm{SO}_{2} \mathrm{CH}_{3}-\mathrm{PCBs}$ (Figure 2). We confirmed the dose-response production of $\mathrm{Cl}_{2}-$ to $\mathrm{Cl}_{5}-\mathrm{OH}-\mathrm{SO}_{2} \mathrm{CH}_{3}-\mathrm{PCBs}$ in experimental mice, and several $\mathrm{Cl}_{3}$ - and $\mathrm{Cl}_{4}-\mathrm{DiOH}-\mathrm{SO}_{2} \mathrm{CH}_{3} \mathrm{PCB}$ congeners were detected in high-dose mice (Figure S2).
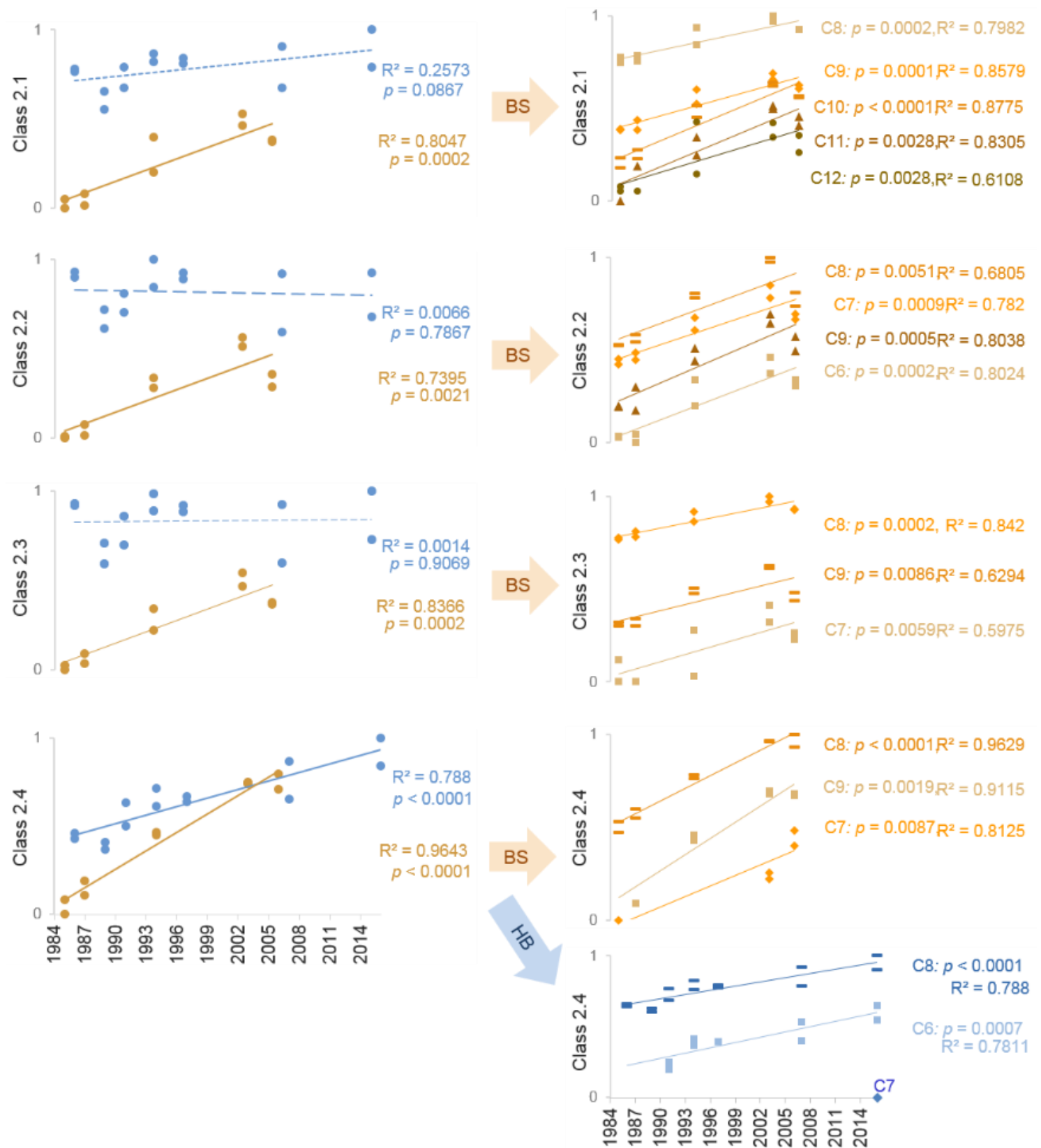

Figure 5. Temporal trends of Class 2.1-2.3 PFSA classes in polar bear serum from Hudson Bay (HB, blue data) and Beaufort Sea (BS, brown data). Solid, dashed and dotted lines indicate regressions with $p<0.05,0.05<p<0.1$ and $p>0.1$, respectively. The $y$-axis represents normalized $\log _{10}$ (IS-corrected peak area) per gram dry serum. 
The final class of PCB metabolites discovered was the PCB-Sulfonates (Class 1.5, $\mathrm{SO}_{3}-\mathrm{PCBs}$ ). These have never been reported in any samples, and > 20 congeners were detected here. MS/MS experiments showed characteristic neutral loss of $\mathrm{SO}_{2}$ (Figure S8), analogous to fragmentation of alkylbenzenesulfonates ${ }^{[9]}$. For the most abundant congeners, diagnostic $\left[\mathrm{SO}_{3}\right]^{-}$and $\left[\mathrm{SO}_{3} \mathrm{Cl}\right]^{-}$fragment ions were also observed, confirming the presence of a sulfonate functional group. The pathway leading to $\mathrm{SO}_{3}$-PCBs is uncertain, however, sulfonic acid metabolites were reported for some compounds ${ }^{[10]}$ whereby the $\mathrm{SO}_{3}$ moiety is either added to a double bond ${ }^{[10 b]}$ or can replace a chlorine atom ${ }^{[10 a]}$. We therefore propose pathways (Figure 2) via oxidation of $\mathrm{PCB}$ thiols, intermediates in $\mathrm{SO}_{2} \mathrm{CH}_{3}-\mathrm{PCB}$ formation, or via gut microflora, which reduce $\mathrm{SO}_{4}{ }^{2-}$ to $\mathrm{SO}_{3} \mathrm{H}^{-}$and add $\mathrm{SO}_{3} \mathrm{H}^{-}$to parent $\mathrm{PCBs}$. We also observed the dose-response production of $\mathrm{Cl}_{2}$ - to $\mathrm{Cl}_{7}-\mathrm{SO}_{3}-\mathrm{PCBs}$ in experimental mice.

Perfluoroalkyl acids such as perfluorooctanesulfonate (PFOS, $\mathrm{C}_{8} \mathrm{~F}_{17} \mathrm{SO}_{3}{ }^{-}$) have been detected in polar bears since $2001^{[11]}$, and only yield saturated perfluoroalkyl fragments during fragmentation (i.e. [ $\mathrm{C}_{n} \mathrm{~F}_{2 n}$ $\left.\left.{ }_{1}\right]^{-}\right)$. The observation of unique in-source fragments such as $\left[\mathrm{C}_{3} \mathrm{~F}_{5}\right]^{-}$and $\left[\mathrm{C}_{2} \mathrm{~F}_{5} \mathrm{O}\right]^{-}$in pooled polar bear serum (Figure 1) were therefore attributable to new classes fluoroalkyl contaminants. The first class are the Cyclic or Unsaturated PFSAs (Class 2.1). These substances share the general chemical formula $\mathrm{C}_{n} \mathrm{~F}_{2 n}$ ${ }_{1} \mathrm{SO}_{3}^{-}$( $\mathrm{n}=8-10, \geq 8$ analytes) and are analogous to PFOS but with 2 fewer $\mathrm{F}$ atoms. In MS/MS spectra, $\left[\mathrm{SO}_{3}\right]^{-}$and $\left[\mathrm{SO}_{3} \mathrm{~F}\right]^{-}$ions were consistent with PFOS (Figure S9), but diagnostic perfluoroalkenyl ions (e.g. $\left.\mathrm{C}_{5} \mathrm{~F}_{9}{ }^{-}\right)$were observed, indicating a ring or double-bond in the core structures, while one isomer produced the $\mathrm{C}_{4} \mathrm{~F}_{7}-$ perfluoroalkenyl ion, most likely indicative of a double bond. Neither unsaturated nor cyclic PFSAs has been reported in polar bears, but a cyclic PFSAs, 4-PFCHS (Table S1), was reported in lake food webs of the Canadian high Arctic ${ }^{[12]}$. $\mathrm{C}_{4}-\mathrm{C}_{13}$ unsaturated or cyclic PFSAs were identified as ingredients in historical aqueous film-forming foams (AFFFs) produced in the United States ${ }^{[13]}$, and we also recently detected the $\mathrm{C}_{7}-\mathrm{C}_{14}$ homologs in fish from China $^{[14]}$.

The second class of new PFSAs are the Ether-PFSAs (Class 2.2, $\mathrm{C}_{n} \mathrm{~F}_{2 n+1} \mathrm{SO}_{4}{ }^{-}, \mathrm{n}=6-9, \geq 13$ analytes), flagged by unique $\left[\mathrm{C}_{2} \mathrm{~F}_{5} \mathrm{O}\right]^{-}$ions and characterized by the simultaneous detection of PFSA-specific ions ([ $\left.\mathrm{SO}_{3}\right]^{-}$, $\left[\mathrm{SO}_{3} \mathrm{~F}\right]^{-}$) and perfluoroalkoxy fragments (e.g. $\left[\mathrm{C}_{2} \mathrm{~F}_{5} \mathrm{O}\right]^{-}$, Figure 4). $A \mathrm{C}_{6}$ analyte detected in serum from AFFF-exposed firefighters in Australia ${ }^{[15]}$ was tentatively proposed as $\mathrm{CF}_{3} \mathrm{OC}_{5} \mathrm{~F}_{10} \mathrm{SO}_{3}{ }^{-}$, and $\mathrm{C}_{7}-\mathrm{C}_{14}$ etherPFSAs were also recently proposed in fish from China ${ }^{[14]}$. The current discovery in polar bears is the first evidence that ether-PFSAs are global contaminants.

The third PFSA class detected is structurally ambiguous, and generally termed Unsaturated Ether-, Cyclic Ether-, or Carbonyl-PFSAs (Class 2.3, $\mathrm{C}_{n} \mathrm{~F}_{2 n-1} \mathrm{SO}_{4}{ }^{-}, \mathrm{n}=7-9, \geq 11$ analytes). MS/MS analyses revealed typical PFSA fragments, perfluoroalkenyl fragments, and neutral loss of perfluoroalkoxy ions (i.e. $\mathrm{C}_{n} \mathrm{~F}_{2 n} \mathrm{O}$ ) for all 
isomers (Figure S10). Homologous compounds matching this class were reported in AFFF-impacted concrete $^{[16]}$ and in fish from China ${ }^{[14]}$. Using patent information, a $C_{6}$-analyte detected in water downstream of a fluorochemical facility was speculated as an enol-ether-PFSA $\left(\mathrm{CF}_{2}=\mathrm{CFOCF}_{2} \mathrm{C}\left(\mathrm{CF}_{3}\right) \mathrm{OC}_{2} \mathrm{~F}_{4} \mathrm{SO}_{3}^{-}\right)^{[17]}$. A $\mathrm{C}_{8}$ analyte in AFFF-exposed firefighters' serum was tentatively proposed as a ketone-PFSA $\left(\mathrm{CF}_{3} \mathrm{C}(\mathrm{O}) \mathrm{C}_{6} \mathrm{~F}_{12} \mathrm{SO}_{3}\right)^{[15]}$. The current discovery in polar bears is also the first evidence of a new global contaminant class.

Table 1. Non-target chemical classes detected in polar bear serum

\begin{tabular}{|c|c|c|c|c|c|}
\hline Group & Class No. & Name & Molecular Formula & $\begin{array}{c}\text { Total Analytes } \\
\text { Detected }\end{array}$ & $\mathrm{CL}^{[\mathrm{a}]}$ \\
\hline \multirow{5}{*}{ 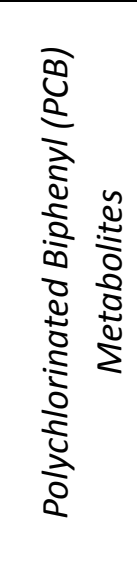 } & 1.1 & $\mathrm{SO}_{4}-\mathrm{PCB}$ & $\begin{array}{c}\mathrm{C}_{12} \mathrm{Cl}_{n} \mathrm{H}_{9-n} \mathrm{SO}_{4}^{-} \\
\mathrm{n}=2-8\end{array}$ & 51 & $1 \& 3^{[b]}$ \\
\hline & 1.2 & $\mathrm{OH}-\mathrm{SO}_{4}-\mathrm{PCB}$ & $\begin{array}{c}\mathrm{C}_{12} \mathrm{Cl}_{n} \mathrm{H}_{9-n} \mathrm{SO}_{5}^{-} \\
\mathrm{n}=3-7\end{array}$ & 42 & 3 \\
\hline & 1.3 & $\mathrm{OH}-\mathrm{SO}_{2} \mathrm{CH}_{3}-\mathrm{PCB}$ & $\begin{array}{c}\mathrm{C}_{13} \mathrm{Cl}_{\mathrm{n}} \mathrm{H}_{11-\mathrm{n}} \mathrm{SO}_{3}^{-} \\
\mathrm{n}=3-8\end{array}$ & 45 & 3 \\
\hline & 1.4 & $\mathrm{DiOH}-\mathrm{SO}_{2} \mathrm{CH}_{3}-\mathrm{PCB}$ & $\begin{array}{c}\mathrm{C}_{13} \mathrm{Cl}_{\mathrm{n}} \mathrm{H}_{11-\mathrm{n}} \mathrm{SO}_{4}^{-} \\
\mathrm{n}=2-7\end{array}$ & 22 & 3 \\
\hline & 1.5 & $\mathrm{SO}_{3}-\mathrm{PCBs}$ & $\begin{array}{c}\mathrm{C}_{12} \mathrm{Cl}_{\mathrm{n}} \mathrm{H}_{11-\mathrm{n}} \mathrm{SO}_{3}^{-} \\
\mathrm{n}=3-6\end{array}$ & 21 & 3 \\
\hline \multirow{4}{*}{ 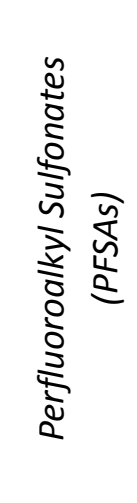 } & 2.1 & Cyclic or Unsaturated PFSAs & $\begin{array}{c}\mathrm{C}_{\mathrm{n}} \mathrm{F}_{2 \mathrm{n}-1} \mathrm{SO}_{3}^{-} \\
\mathrm{n}=8-10\end{array}$ & 8 & 3 \\
\hline & 2.2 & Ether PFSAs & $\begin{array}{c}\mathrm{C}_{n} \mathrm{~F}_{2 n+1} \mathrm{SO}_{4}^{-} \\
\mathrm{n}=6-9\end{array}$ & 13 & 3 \\
\hline & 2.3 & $\begin{array}{l}\text { Unsaturated Ether-, Cyclic } \\
\text { Ether- or Carbonyl PFSAs }\end{array}$ & $\begin{array}{c}\mathrm{C}_{n} \mathrm{~F}_{2 \mathrm{n}-1} \mathrm{SO}_{4}^{-} \\
\mathrm{n}=7-9\end{array}$ & 11 & 3 \\
\hline & 2.4 & $\begin{array}{c}\text { x:2 Chlorinated } \\
\text { Perfluoroalkyl } \\
\text { Ether Sulfonates }\end{array}$ & $\begin{array}{c}\mathrm{ClC}_{n} \mathrm{~F}_{2 \mathrm{n}} \mathrm{SO}_{4}^{-} \\
\mathrm{n}=6-8\end{array}$ & 3 & $1 \& 2^{[b]}$ \\
\hline \multirow{5}{*}{ 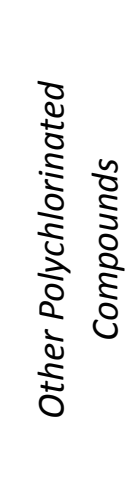 } & 3.1 & Chlorinated Aromatics & $\begin{array}{c}\mathrm{C}_{8} \mathrm{Cl}_{n} \mathrm{H}_{7-\mathrm{n}} \mathrm{O}^{-} \\
\mathrm{n}=6-7\end{array}$ & 2 & 4 \\
\hline & 3.2 & $\begin{array}{c}\text { Tetrachloro Aromatic } \\
\text { Sulfate }\end{array}$ & $\mathrm{C}_{14} \mathrm{Cl}_{4} \mathrm{H}_{7} \mathrm{SO}_{4}^{-}$ & 1 & 4 \\
\hline & 3.3 & $\begin{array}{l}\text { Heptachlorinated } \\
\text { Hydroxylated } \\
\text { Nitroaromatics }\end{array}$ & $\begin{array}{l}\mathrm{C}_{14} \mathrm{Cl}_{7} \mathrm{H}_{5} \mathrm{NO}_{6}^{-} \\
\mathrm{C}_{14} \mathrm{Cl}_{7} \mathrm{H}_{7} \mathrm{NO}_{6}^{-}\end{array}$ & $\begin{array}{l}1 \\
1\end{array}$ & 4 \\
\hline & 3.4 & Hexachlorinated & $\mathrm{C}_{15} \mathrm{Cl}_{6} \mathrm{H}_{13} \mathrm{O}_{5}^{-}$ & 2 & 4 \\
\hline & & Compounds & $\mathrm{C}_{15} \mathrm{Cl}_{6} \mathrm{H}_{15} \mathrm{O}_{3}^{-}$ & 1 & \\
\hline
\end{tabular}

[a] CL" confidence level of the proposed structure, assigned based on criteria proposed by Schymanski et al. ${ }^{[18]}$

[b] $\mathrm{CL}=1$ was assigned to only some congeners or isomers due to the availability of authentic standards. 
The final PFSA class, flagged by in-source $[\mathrm{Cl}]^{-}$and confirmed by authentic $\mathrm{F}-53 \mathrm{~B}$ standard $\left(\mathrm{CClF}_{2} \mathrm{C}_{5} \mathrm{~F}_{10} \mathrm{OC}_{2} \mathrm{~F}_{4} \mathrm{SO}_{3}{ }^{-}\right.$, Table S1), are the $\mathbf{x : 2}$ Chlorine Substituted Perfluoroalkyl Ether Sulfonates (Class

2.4, $\mathrm{ClC}_{\mathrm{n}} \mathrm{F}_{2 \mathrm{n}} \mathrm{SO}_{4}^{-}, \mathrm{n}=6-8,3$ analytes). $\mathrm{F}-53 \mathrm{~B}$ is a mist suppressant used only in China since the late $1970 \mathrm{~s}^{[19]}$, and $C_{7}-C_{12}$ homologs have been detected in samples from China ${ }^{[14,19]}$. F-53B was recently report in Greenland polar bears ${ }^{[20]}$, but our study is the first report of the $C_{6}$ and $C_{7}$-homologs in polar bears, and the first report of $\mathrm{C}_{6}$ in the environment.

Four classes of other new polychlorinated compounds were also detected and assigned unambiguous empirical formulas; albeit the core structures remain uncertain. The first 3 classes were chlorinated aromatics with $\mathrm{OH}$ - (Class 3.1 and 3.3), $\mathrm{SO}_{4-}^{-}$(Class 3.2) or $\mathrm{NO}_{2}$ - functionality (Class 3.3). The $\mathrm{Cl}_{7}$ homolog in Class $3.1\left(\mathrm{C}_{8} \mathrm{Cl}_{n} \mathrm{H}_{7-n} \mathrm{O}^{-}\right.$, $\mathrm{n}=6-7$, Figure S12) shares the same molecular formula with 4-hydroxyheptachlorostyrene (4-OH-HpCS, Table S1), a suspect octachlorostyrene metabolite only once reported in polar bears ${ }^{[21]}$. Based on $\mathrm{MS}^{\mathrm{n}}$ experiments (Figure S13), the single Class 3.2 analyte $\left(\mathrm{C}_{14} \mathrm{Cl}_{4} \mathrm{H}_{7} \mathrm{SO}_{4}{ }^{-}\right)$was consistent with a sulfated metabolite of dichlorodiphenyldichloroethylene, which could possibly be formed by sulfation of hydroxylated DDE, a metabolite has been detected in seals ${ }^{[22]}$. One possible structure for the $\mathrm{C}_{14} \mathrm{Cl}_{7} \mathrm{H}_{5} \mathrm{NO}_{6}{ }^{-}$in Class 3.3 is a hydroxylated nitro-polychlorinated diphenyl ether $(\mathrm{OH}$ $\mathrm{NO}_{2}-\mathrm{PCDE}$, Figure S14). Some legacy herbicides are nitro-PCDEs ${ }^{[23]}$, and could be oxidized to $\mathrm{OH}-\mathrm{NO}_{2}-$ PCDEs.

To examine the time trends of these new halogenated contaminants, we further analyzed pooled male serum from the archive going back to the mid-1980s for the Hudson Bay and Beaufort Sea subpopulations (Table S4). Two pooled samples were generated for each year examined. After spiking with internal standards (Table S1), all samples were extracted with the stir bar-assisted sorptive method and screened by Nt-HRMS for all contaminants discovered here. Linear regression was run for internal standard corrected total response within each class to test for significant temporal trends. All 5 classes of PCB metabolites had stable trends in both locations (Figure S16) but significant increasing trends were detected for all 4 PFSA classes (Class 2.1-2.4) in Beaufort Sea (1985-2006) and for Class 2.4 in Hudson Bay (1985-2006, Figure 5). Class 2.1-2.3 had doubling times between 7.0-9.0 years in Beaufort Sea (Figure S17). The distinctly lower doubling time for Class 2.4 in the Beaufort Sea subpopulation (3.7 years, 95\% confidence interval 3.2-4.5) than in Hudson Bay (8.1 years, 95\% confidence interval 6.1-11.9) is consistent with the source of this class coming from China ${ }^{[19]}$, as the Bering Sea receives inflow from the North Pacific Ocean through the Bering Strait. For classes showing increasing trends, all individual homologues within the class were tested and had similar increasing trends (Figure 5) and comparable doubling times (Figure S17). 
By combining a sensitive new extraction step with our Nt-HRMS methods, more than 200 new organohalogen compounds were detected in polar bear serum. Their detection in two distinct and distant subpopulations, and in archived samples dating to the mid-1980s indicates long and wide contamination of the Arctic with these previously unknown persistent and bioaccumulative chemicals whose toxicity remains unknown. The contamination of top predator polar bears suggests exposure to the same contaminants in the underlying marine foodweb, and the mouse study provides evidence that other mammals, including people, may be exposed to the 5 novel classes of PCB metabolites. Considering regulatory restrictions and controls implemented for the past 1-2 decades, the detected stable PCB metabolite trends and increasing PFSAs for the past 3 decades in polar bears are worth further study. The presence of these substances in blood means they could disrupt normal physiology, as related $\mathrm{OH}-\mathrm{PCBs}^{[24]}, \mathrm{PFSAs}^{[25]}$ and $4-\mathrm{OH}-\mathrm{HpCS}^{[21]}$ bind to serum proteins and can thereby disrupt hormone homeostasis. For example, $\mathrm{SO}_{4}-\mathrm{PCBs}$ bind to estrogen and androgen receptors ${ }^{[26]}$. The new chlorinated aromatics compounds (Class 3.1-3.4) may also be bioactivated to reactive intermediates (e.g. epoxides), just as PCBs ${ }^{[6 a]}$. While challenging, understanding the individual- and population-level effects of these new contaminants raises additional concerns for the conservation and management of polar bears in a changing climate ${ }^{[27]}$

\section{Supporting Information}

Details of all experiments and compound characterization are provided in the Supplementary Information (SI).

\section{Acknowledgements}

Funding for this project was from that Natural Sciences and Engineering Research Council of Canada (NSERC, Martin PI). The synthesis of PCB metabolite standards and the mouse study were respectively supported by grants ES013661 (Lehmler PI) and ES019487, ES025708 and GM111381 (Cui PI) from the National Institutes of Health of the United States (NIH). Additional research support was provided by the Environmental Health Sciences Research Center (NIH ES005605) and the Center for Ecogenetics and Environmental Health (NIH ES0007033). Financial support to Yanna Liu was the Chinese Scholarship Council, and Killam Trusts. Dr. Amila O De Silva (Environment and Climate Change Canada) provided the 4-PFECHS standard.

\section{References}

[1] R. J. Letcher, A. D. Morris, M. Dyck, E. Sverko, E. J. Reiner, D. A. D. Blair, S. G. Chu, L. Shen, Sci Total Environ 2018, 610611, 121-136.

[2] Stockholm-Convention., Stockholm Convention, Geneva, Switzerland, 2009. 
[3] E. Simon, M. van Velzen, S. H. Brandsma, E. Lie, K. Loken, J. de Boer, J. Bytingsvik, B. M. Jenssen, J. Aars, T. Hamers, M. H. Lamoree, Environ Sci Technol 2013, 47, 8902-8912.

[4] R. J. Letcher, J. O. Bustnes, R. Dietz, B. M. Jenssen, E. H. Jorgensen, C. Sonne, J. Verreault, M. M. Vijayan, G. W. Gabrielsen, Sci Total Environ 2010, 408, 2995-3043.

[5] Y. Liu, P. A.S., J. W. Martin, Anal Chem 2015, 87, 4260-4268.

[6] a) F. A. Grimm, D. Hu, I. Kania-Korwel, H. J. Lehmler, G. Ludewig, K. C. Hornbuckle, M. W. Duffel, A. Bergman, L. W. Robertson, Crit Rev Toxicol 2015, 45, 245-272; b) K. Dhakal, X. He, H. J. Lehmler, L. M. Teesch, M. W. Duffel, L. W. Robertson, Chem Res Toxicol 2012, 25, 2796-2804.

[7] a) G. M. Sandala, C. Sonne-Hansen, R. Dietz, D. C. Muir, K. Valters, E. R. Bennett, E. W. Born, R. J. Letcher, Sci Total Environ 2004, 331, 125-141; b) R. Letcher, Government of Nunavut, Department of Environment, 2007.

[8] K. Haraguchi, H. Kuroki, Y. Masuda, Chemosphere 1987, 16, 2033-2038.

[9] V. Andreu, Y. Picó, Anal Chem 2004, 76, 2878-2885.

[10] a) S. J. Kalkhoff, D. W. Kolpin, E. M. Thurman, I. Ferrer, D. Barcelo, Environ Sci Technol 1998, 32, 1738-1740; b) X. He, J. Li, H. Gao, F. Qiu, K. Hu, X. Cui, X. Yao, Drug Metab Dispos 2003, 31, 983-985.

[11] J. P. Giesy, K. Kannan, Environ Sci Technol 2001, 35, 1339-1342.

[12] G. L. Lescord, K. A. Kidd, A. O. De Silva, M. Williamson, C. Spencer, X. Wang, D. C. Muir, Environ Sci Technol 2015, 49, 2694-2702.

[13] K. A. Barzen-Hanson, S. C. Roberts, S. Choyke, K. Oetjen, A. McAlees, N. Riddell, R. McCrindle, P. L. Ferguson, C. P. Higgins, J. A. Field, Environ Sci Technol 2017, 51, 2047-2057.

[14] Y. Liu, M. Qian, X. Ma, L. Zhu, J. W. Martin, Environ Sci Technol 2018, 52, 5830-5840.

[15] A. Rotander, A. Karrman, L. M. Toms, M. Kay, J. F. Mueller, M. J. Gomez Ramos, Environ Sci Technol 2015, 49, 24342442.

[16] C. Baduel, J. F. Mueller, A. Rotander, J. Corfield, M. J. Gomez-Ramos, Chemosphere 2017, 185, $1030-1038$.

[17] M. Strynar, S. Dagnino, R. McMahen, S. Liang, A. Lindstrom, E. Andersen, L. McMillan, M. Thurman, I. Ferrer, C. Ball, Environ Sci Technol 2015, 49, 11622-11630.

[18] E. L. Schymanski, J. Jeon, R. Gulde, K. Fenner, M. Ruff, H. P. Singer, J. Hollender, Environ Sci Technol 2014, 48, 20972098.

[19] S. Wang, J. Huang, Y. Yang, Y. Hui, Y. Ge, T. Larssen, G. Yu, S. Deng, B. Wang, C. Harman, Environ Sci Technol 2013, 47, 10163-10170.

[20] W. A. Gebbink, R. Bossi, F. F. Riget, A. Rosing-Asvid, C. Sonne, R. Dietz, Chemosphere 2016, 144, $2384-2391$.

[21] C. D. Sandau, I. A. T. M. Meerts, Environ Sci Technol 2000, 34, 3871.

[22] B. Jansson, S. Jensen, M. Olsson, L. Renberg, G. Sundstrom, R. Vaz, Ambio 1975, 4, 93-97.

[23] F. Adams, Anthropogenic contaminants, Vol. 3K, Springer Berlin Heidelberg, Berlin, Heidelberg, 1990.

[24] P. D. Jones, W. Hu, W. De Coen, J. L. Newsted, J. P. Giesy, Environ Toxicol Chem 2003, 22, 2639-2649.

[25] J. M. Weiss, P. L. Andersson, M. H. Lamoree, P. E. Leonards, S. P. van Leeuwen, T. Hamers, Toxicol Sci 2009, 109, 206216.

[26] S. Flor, X. He, H. J. Lehmler, G. Ludewig, Environ Sci Pollut Res Int 2016, 23, 2186-2200.

[27] a) M. A. McKinney, E. Peacock, R. J. Letcher, Environ Sci Technol 2009, 43, 4334-4339; b) J. F. Bromaghin, T. L. McDonald, I. Stirling, A. E. Derocher, E. S. Richardson, E. V. Regehr, D. C. Douglas, G. M. Durner, T. Atwood, S. C. Amstrup, Ecol Appl 2015, 25, 634-651. 